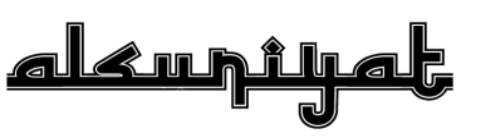

JURNAL PENELITIAN BAHASA, SASTRA, DAN

BUDAYA ARAB

P-ISSN: 2615-7241 | E-ISSN: 2721-480X // Vol. 2 No. 2 | 95-108

(1) https://ejournal.upi.edu/index.php/alsuniyat/index

\title{
EVALUASI PENERAPAN BLENDED LEARNING PADA PEMBELAJARAN BAHASA ARAB DI SMPIT IBADURRAHMAN: STUDI KASUS DI KELAS VII AKHWAT
}

\author{
Fahtu Khaerunnisa \\ Universitas Pendidikan Indonesia Bandung, Indonesia \\ E-mail: fahtukhaerunnisa@yahoo.com
}

\begin{abstract}
:
The purpose of this study is to provide an overview about the application of blended learning especially during the distance education. This study used a qualitative approach with case study methods. Data collection conducted through interviews, observations and documentation studies. Based on the results of the study, in the learning planning activities, teacher prepared lesson plan, syllabus, face-to-face scheduling, teaching materials and evaluation tools that form as soft files. The learning process is carried out in three stages: the initial, core and final activities. Evaluation of learning in the form of assignments, midterm and final examination. When the implementation of blended learning used there are several obstacles that teachers feel
\end{abstract}

Keywords:

Blended learning; Evaluation; Arabic language

\begin{abstract}
Abstrak:
Tujuan penelitian ini adalah untuk memberikan gambaran tentang penerapan blended learning khususnya pada saat Pembelajaran Jarak Jauh (PJJ) berlangsung. Penelitian ini menggunakan pendekatan kualitatif dengan metode study kasus. Pengumpulan data yang dilakukan melalui wawancara, observasi dan studi dokumentasi. Berdasarkan hasil dari penelitian, pada proses perencanaan guru mempersiapkan RPP, silabus, penjadwalan tatap muka, bahan ajar dan alat evaluasi yang berbentuk soft file. Proses pembelajaran dilakukan dengan tiga tahap yaitu kegiatan awal, inti dan akhir. Evaluasi pembelajaran berupa pemberian tugas, UTS serta UAS. Pada saat pelaksanaannya terdapat beberapa kendala yang dirasakan guru

Kata Kunci:

Blended learning; Evaluasi; Bahasa Arab
\end{abstract}

\section{PENDAHULUAN}

Proses pendidikan saat ini telah bergeser sesuai dengan perkembangan zaman dan mengalami perubahan yang pesat dengan memanfaatkan teknologi digital, dimana teknologi tersebut digunakan untuk kepentingan peningkatan dan kualitas pendidikan. Kerangka kompetensi abad 21 menunjukan bahwa peserta didik dituntut agar mampu mengasah kemampuan intelektualnya artinya tidak hanya berpengetahuan tetapi juga harus dilengkapi dengan keterampilan berpikir tingkat tinggi dan didukung dengan kemampuan memanfaatkan teknologi informasi dan komunikasi.

Senada dengan pendapat tersebut Wardani, dkk (2018:13) mengungkapkan bahwa, proses pemanfaatan teknologi pada pembelajaran biasa disebut dengan pembelajaran elektronik atau e-learning. Akan tetapi proses pembelajaran yang hanya memanfaatkan 
teknologi saja atau yang hanya menerapkan e-learning tidak dapat sepenuhnya berhasil hal tersebut dikarenakan gaya belajar masing-masing peserta didik berbeda.

Menurut Bobby De Porter dan Mike Hernacki (dalam Nikmawati, 2014:24) gaya belajar dikelompokan menjadi tiga, yaitu gaya belajar visual, gaya belajar audio dan gaya belajar kinestetik. Para peserta didik yang memiliki gaya belajar visual dan audio mungkin akan berhasil dalam mengikuti pembelajaran menggunakan e-learning akan tetapi untuk peserta didik yang memiliki gaya belajar kinestetik mungkin memiliki kesempatan kecil akan berhasil pada proses pembelajaran. Pendapat tersebut didukung juga oleh pendapat Wildavsky (dalam Wena, 2014:214) bahwa kelemahan utama pembelajaran e-learning, yaitu intensitas bertemu antara pengajar dan peserta didik sangat minim serta sulit untuk dapat melakukan sosialisasi antar peserta didik.

Dari pendapat tersebut dapat ditarik kesimpulan bahwa komunikasi baik antara guru dan peserta didik maupun peserta didik dengan peserta didik masih sangat penting untuk dilakukan. Mengingat bahwa dengan berkomunikasi akan lebih mudah diketahui sejauh mana pembelajaran tersebut berjalan dengan baik.

Wardani, dkk. (2018:14) berpendapat bahwa pembelajaran tatap muka sangat penting juga untuk diterapkan akan tetapi melihat perkembangan teknologi yang sangat luas guru juga harus bisa memanfaatkannya agar dapat menarik minat peserta didik mengikuti proses pembelajaran dan mengikuti mata pelajaran tersebut. Oleh karena itu, salah satu cara untuk mengatasi masalah tersebut yaitu dengan menerapkan blended learning sehingga para peserta didik tertarik untuk mengikuti proses pembelajaran.

Salah satu mata pelajaran yang melakukan blended learning adalah mata pelajaran bahasa Arab yang terdapat di SMPIT Ibadurrahman. Menurut Muhammad (dalam Thoha, 2012:82) bahasa Arab merupakan satu disiplin ilmu yang terdiri dari berbagai aspek keterampilan utama didalamnya. Aspek utama tersebut meliputi keterampilan mendengar (mahârah al-istimâ'), keterampilan berbicara (mahârah al-kalam), keterampilan membaca (mahârah al-qirấah) dan keterampilan menulis (mahârah al-kitâbah).

Taufik (dalam Karimna, 2019, 58-59) ada empat keterampilan yang harus dikuasai oleh murid ketika mempelajari bahasa Arab. Empat keterampilan tersebut adalah: Keterampilan membaca (qirā'ah), keterampilan menulis (kitābah), keterampilan menyimak (istimā') dan keterampilan berbicara (takallum). Keempat keterampilan tersebut saling berkaitan dan 
saling mempengaruhi. Tidak terkecuali, keterampilan berbicara (takallum) yang merupakan keterampilan pokok dalam belajar bahasa.

Dari observasi, dapat diketahui bahwa SMPIT Ibdaurrahman memiliki kesiapan dalam melaksanakan blended learning pada kegiatan belajar mengajarnya. Dan kesiapan tersebut bukan hanya terdapat dari guru maupun pengelola sekolah akan tetapi para peserta didik, serta fasilitas dikedua belah pihak pun dirasa cukup siap dan memadai untuk dilaksanakannya blended learning.

Oleh karena itu peneliti tertarik untuk membahas perihal blended learning yang dilakukan di SMPIT Ibadurrahman khususnya dikelas VII akhwat dengan mata pelajaran bahasa Arab. Adapun persoalan yang akan dibahas adalah seputar, persiapan yang dilakukan guru, proses pelaksanaan pembelajaran, evaluasi pembelajaran yang dilakukan guru serta kendala yang dihadapi guru selama melakukan blended learning.

\section{METODE}

Pada peneltian ini metode yang digunakan adalah studi kasus (case study) dengan pendekatan kualitatif. Studi kasus (case study) adalah sebuah model yang memfokuskan eksplorasi "sistem terbatas" (bounded system) atas satu kasus ataupun pada sebagian kasus secara terperinci dengan menggalian data secara mendalam. Beragam sumber informasi yang kaya akan konteks dilakukan untuk penggalian data (Cresswell, 2015). Pada pendekatan kualitatif, data yang digunakan berasal dari naskah wawancara, observasi dan studi dokumentasi. Pada penelitian ini terdiri dari 34 peserta didik yang semuanya merupakan peserta didik perempuan. Semua peserta didik berjenis kelamin perempuan dikarenakan di SMPIT Ibadurrahman peserta didik laki-laki dan perempuan memiliki kelas yang terpisah.

Penelitian ini dilaksanakan di SMPIT Ibadurrahman yang berlokasi di Komplek Bumi Ciruas Permai 1 Blok C8 No. 14-15 Rt. 10 Rw. 04, Ranjeng, Kec. Ciruas, Serang, Banten. Lokasi ini peneliti pilih karena SMPIT Ibadurrahman memiliki kesiapan baik dari guru, peserta didik serta fasilitas yang mempumpuni sehingga blended learning dapat dilaksanakan.

Pada penelitian ini kehadiran peneliti yaitu sebagai pengumpul data dan sebagai instrument aktif dalam upaya mengumpulkan data-data di lapangan. Sedangkan Teknik dan instrument pengumpulan data yang akan peneliti lakukan dalam penelitian ini adalah observasi, wawancara dan studi dokumentasi. Adapun tahapan pengumpulan data diperoleh 
melalui lima langkah utama seperti, tahap orientasi, tahap eksplorasi, tahap member check, tahap triangulasi dan tahap audit trail.

Sedangkan teknik analisis data yang digunakan peneliti adalah menggunakan teknik analisis data kualitatif yaitu data yang berbentuk uraian sehingga menuntut peneliti untuk menafsirkan secara mendalam. Hal ini dilakukan peneliti karena sesuai dengan karakteristik masalah dalam penelitian ini.

\section{HASIL DAN PEMBAHASAN}

Berikut ini peneliti deskripsikan hasil dan pembahasan berdasarkan masing-masing fokus permasalahan yang ingin peniti kaji secara mendalam terkait penerapan pembelajaran blended learning pada pembelajaran bahasa Arab di SMPIT Ibadurrahman.

\section{Perencanaan Guru dalam Penerapan Blended Learning pada Pembelajaran Bahasa Arab di SMPIT Ibadurrahman.}

Berdasarkan hasil wawancara yang dilakukan peneliti dengan guru mata pelajaran bahasa Arab di SMPIT Ibadurrahman, penerapan blended learning yang dilaksanakan merupakan program peningkatan mutu belajar dengan cara memanfaatkan kemajuan teknologi komunikasi dan informasi yang semakin pesat. Tujuan lainnya adalah agar kegiatan belajar peserta didik bisa dilakukan dimana saja dengan waktu yang tak terbatas seperti di sekolah. Peserta didik selalu dapat mengulang kembali pelajaran tersebut meskipun tidak sedang berada didalam kelas.

Pemilihan mata pelajaran bahasa Arab sebagai uji coba dalam program ini mengingat bahwa mata pelajaran bahasa Arab merupakan mata pelajaran muatan lokal dan juga guru bidang studi yang dirasa memiliki kompetensi baik dari segi kreatifitas yang dimiliki guru serta kemampuan untuk memanfaatkan teknologi yang ada.

Selain itu blended learning ini merupakan cara pengaplikasian dari program Pendidikan Jarak Jauh (PJJ) yang beberapa tahun lalu telah digaungkan oleh para akademis pendidikan sebagai bentuk pemanfaatan teknologi khususnya dalam bidang pendidikan.

Menurut RISTEKDIKTI (2016) Pendidikan Jarak Jauh (PJJ) merupakan proses pendidikan yang terorganisasi yang menjembatani keterpisahan antara siswa dengan pendidik dan dimediasi oleh pemanfaatan teknologi, dan pertemuan tatap muka yang minimal. Sedangkan dalam Undang-undang Nomor 12 Tahun 2012 pasal 31 tentang pendidikan tinggi menyebutkan bahwa pendidikan jarak jauh merupakan proses belajar mengajar yang dilakukan secara jarak jauh melalui penggunaan berbagai media komunikasi 
(teknologi informasi dan teknologi). Sehingga dapat diketahui bahwa Pembelajaran Jarak Jauh atau yang biasa disingkat menjadi PJJ adalah sebuah proses kegiatan belajar mengajar yang dapat dilaksanakan dimana saja meskipun tidak dalam ruang lingkup sekolah, dengan memanfaatkan teknologi informasi dan informasi.

Adapun pelaksanaan pendidikan jarak jauh yang dilaksanakan di SMPIT Ibadurrahman telah dimulai pada tanggal 16 Maret 2019 sesuai dengan kesepakatan pihak sekolah. Proses pendidikan jarak jauh yang dilakukan di SMPIT Ibadurrahman tidak sematamata hanya dilakukan dengan cara e-learning akan tetapi dengan blended learning.

E-leaning merupakan model pembelajaran online (pembelajaran jarak jauh) yang diharapkan mampu menggeser model pembelajaran konvensional yang dianggap selama ini memiliki kekurangan. Namun demikian, dalam implementasinya model pembelajaran $e$ learning memiliki serangkaian keterbatasan dibandingkan dengan pembelajaran secara tatap muka (face to face). Sedangkan blended learning adalah suatu pembelajaran yang menggabungkan penerapan pembelajaran tradisional didalam kelas dengan pembelajaran online yang memanfaatkan teknologi informasi (Usman, 2018:138).

Sehingga dapat ditarik kesimpulan bahwa blended learning adalah proses pembelajaran yang mengutamakan terjadinya komunikasi dua arah antara guru dengan peserta didik ataupun peserta didik dengan peserta didik meskipun pembelajaran yang dilakukan berbasis e-learning. Komunikasi yang dilakukan dapat berupa pembelajaran secara tatap muka atau dengan virtual classroom melalui aplikasi pendukung.

Dalam perencanaan penerapannya guru mata pelajaran bahasa Arab di SMPIT Ibadurrahman melaksanakan beberapa tahapan perencanaan pembelajaran seperti; pembuatan jadwal, penentuan tujuan, pembuatan bahan ajar, penyusunan alat evaluasi. Seluruh dokumen perencanaan pembelajaran disiapkan guru dalam bentuk non-cetak berbasis multimedia (soft file) seperti word, power point atau pdf.

Menurut Seel, dkk (dalam Anggraeni dan Akbar, 2018:62) perencanaan pembelajaran berfungsi sebagai kerangka acuan dan aturan dalam pengembangan pembelajaran yang mengarah pada peningkatan pembelajaran dan mempengaruhi motivasi dan sikap peserta didik sedemikian rupa sehingga mereka dapat mencapai pemahaman yang lebih dalam tentang pokok bahasan yang dipelajarinya.

Pelaksanaan guru mata pelajaran bahasa Arab di SMPIT Ibadurrahman dalam perancanaan pelaksanaan blended learning sesuai dengan pendapat Carman (dalam Widiara, 
2018:51) bahwa terdapat lima kunci untuk melaksanakan pembelajaran dengan menggunakan blended learning:

a. Live Event. Pembelajaran langsung atau tatap muka (instructor-led instruction) secara sinkronous dalam waktu dan tempat yang sama (classroom) ataupun waktu yang sama tapi tempat yang berbeda (virtual classroom).

b. Self-Paced Learning. Yaitu, mengkombinasikan dengan pembelajaran mandiri (selfpaced learning) yang memungkinkan peserta didik belajar kapan saja, dimana saja dengan menggunakan berbagai konten (bahan ajar) yang dirancang khusus untuk belajar mandiri baik yang bersifat text-based maupun multimedia-based (video, simulasi, gambar, audio atau kombinasi dari semuanya).

c. Collaboration. Mengkombinasikan baik peserta didik maupun pendidik yang keduaduanya bisa lintas sekolah atau kampus. Dengan demikian perancang blended learning harus meramu bentuk-bentuk kolaborasi, bai kantar teman sejawat maupun kolaborasi antar peserta didik dan pendidik melalui tool-tool komunikasi yang memungkinkan. Seperti, chatroom, forum diskusi, email, website/weblog atau mobile phone.

d. Assesment. Dalam blended learning perancang harus mampu meramu kombinasi jenis penilaian baik yang bersifat tes maupun non-tes atau yang lebih bersifat otentik (authentic assessment/portofolio).

e. Performance Support Materials. Jika kita ingin mengkombinasikan antara pembelajaran tatap muka di kelas dengan pembelajaran tatap muka virtual, perhatikan sumber daya untuk mendukung hal tersebut siap atau tidak, ada atau tidak. Bahan belajar disiapkan dalam bentuk digital, apakah bahan ajar tersebut dapat diakses peserta didik baik secara offline (dalam bentuk CD, MP3 atau DVD).

f. Sedangkan sarana dan prasarana yang digunakan dalam pelaksanaan blended learning hanya mengandalkan teknologi komunikasi dan informasi. Untuk pembelajaran online guru mempersiapkan beberapa video atau gambar pembelajaran yang relevan dengan materi yang akan diajarkan yang nantinya akan dikirim kepada peserta didik melalui aplikasi pesan elektronik seperti Whatsapp. Hal ini dikarenakan tidak adanya LMS (Learning Management System) yang digunakan atau dimiliki sekolah. Sedangkan sarana lain yang didapatkan guru dari sekolah, berupa kuota internet yang diberikan dalam bentuk uang tunai. Sehingga 
pembelian kuota internet dilakukan secara mandiri. Sedangkan perangkat penunjang pembelajaran online tidak diberikan karena guru menggunakan PC sendiri selain itu tidak adanya pelatihan yang didapatkan guru dari sekolah sebelum dilaksanakannya pendidikan jarak jauh. Untuk pembelajaran tatap muka guru memanfaatkan berbagai aplikasi yang mendukung terselenggaranya virtual classroom seperti aplikasi Zoom ataupun Google Meet.

Berdasarkan temuan diatas amat disayangkan sekolah belum memiliki LMS ataupun memanfaatkan LMS yang sudah banyak tersebar diberbagai website pendidikan. Mengingat kegunaan LMS pada saat blended learning amat sangat dibutuhkan demi mendukung proses pendidikan jaraj jauh. Selain itu juga.

Seperti yang diungkapkan Falimbany (2019) blended learning akan berjalan baik bila didukung dengan adanya Learning Management System (LMS). Pada dasarnya LMS ini adalah aplikasi yang bisa membantu dalam merencanakan dan mengimplementasikan pembelajaran. Fungsi LMS memungkinkan pengelola membuat sebuah kursus atau pelatihan dengan mudah dan memonitor peserta pelatihan. Dalam kaitannya dengan blended learning bahwa LMS dapat diandalkan dalam mendukung proses belajar. Sebab keduanya saling melengkapi dan berkaitan. Oleh karena itu penting bagi institusi pendidikan menggunakan LMS terbaik dalam menerapkan blended learning.

\section{Proses Penerapan Blended Learning pada Pembelajaran Bahasa Arab di SMPIT Ibadurrahman}

Berdasarkan hasil penelitian yang dilakukan peneliti, dapat diketahui bahwa pelaksanaan blended learning di SMPIT Ibdadurrahman baru berjalan selama dua bulan dan kemungkinan akan terus berjalan sampai tiga bulan, terhitung dari mulai bulan Maret sampai dengan Juni 2019.

Pembelajaran bahasa Arab dikelas 7 akhwat dilaksanakan setiap hari Jumat pukul 08.00 WIB. Pada pukul 08.00 guru akan melaksanakan virtual classroom dan kemudian membagikan video pembelajaran maupun tugas. Adapun batas akhir pengerjaan tugas dibatasi guru sampai dengan pukul 15.00 WIB. Sehingga murid diharapkan dapat mengumpulkan tugas sebelum batas yang ditentukan.

Pelaksanaan blended learning pada pembelajaran bahasa Arab di SMPIT Ibadurrahman dilaksanakan secara online dan tatap muka, akan tetapi tatap muka yang 
dimaksudkan adalah hanya tatap muka secara virtual melalui aplikasi Zoom atau Google Meet.

Pada kegiatan awal pembelajaran guru akan mengirimkan pesan melalui grup Whatsapp peserta didik. Pesan tersebut berisikan ucapan salam serta menanyakan kesiapan peserta didik untuk mengikuti virtual classroom yang akan diselenggarakan. Setelah dirasa siap, maka guru akan membagikan link virtual classroom agar peserta didik dapat bergabung. Pada saat awal pelaksanaan virtual classroom guru akan memulai pembelajaran dengan cara memberikan salam, berdoa, mengabsen kemudian mengulas sedikit materi sebelumnya. Guru juga melakukan apersepsi dan menjelaskan tujuan pembelajaran sebelum membahas materi pada hari itu. Kegiatan awal yang dilakukan guru sudah baik dan benar.

Merujuk pada pendapat Sukirman dan Kasmad (dalam Anggraeni dan Akbar, 2018:63) pada kegiatan membuka pembelajaran antara lain dapat dilakukan dengan menumbuhkan perhatian dan motivasi; menciptakan sikap yang mendidik; menciptakan kesiapan belajar siswa; meciptakan suasana belajar yang demokratis; mengecek kehadiran siswa; mengecek kesiapan siswa yang lalu dan mengaitkannya dengan materi yang akan dipelajari; menyiapkan tujuan/kompetensi yang akan dicapai; menjelaskan kegiatan-kegiatan atau pengalaman pembelajaran yang harus dilakukan oleh siswa.

Pada kegiatan inti guru akan memberikan beberapa kosakata baru yang berkaitan dengan materi pembelajaran kemudian meminta peserta didik untuk mencatat kosakata tersebut dan memilih beberapa diantaranya untuk membacakan kosakata yang telah dituliskan. Setelah itu guru membagikan video atau gambar kepada peserta didik melalui grup Whatsapp dan menjelaskan isi video ataupun gambar tersebut. Jika materi yang sedang disampaikan berkaitan dengan kemahiran berbicara (mahârah kalâm) atau kemahiran membaca (mahârah qirâ'ah) maka guru akan meminta peserta didik untuk membacakan teks Arab tersebut dengan cara bergilir namun secara pemilihan peserta didik dilakukan secara acak. Pada kegiatan ini secara tidak langsung akan mengasah juga keterampilan mendengar (mahârah istima'). Sedangkan penjelasan yang berkaitan dengan keterampilan menulis (mahârah kitâbah) dilakukan guru dengan cama memanfaatkan fitur share screen yang terdapat pada aplikasi Zoom tersebut.

Kegiatan inti yang dilakukan guru cukup maksimal karena guru dirasa telah dapat memanfaatkan teknologi dengan baik, sehingga pelaksanaan virtual classroom yang dilakukan tidak monoton dan dapat menarik minat siswa. 
Seperti pendapat yang dikemukakan oleh Sukirman dan Kasmad (dalam Anggraeni dan Akbar, 2018:64) kegiatan inti pembelajaran harus dapat menciptakan kondisi pembelajaran yang interaktif, inspiratif, menyenangkan, menantang, memotivasi peserta didik, prakarsa, kreativitas dan menumbuhkan kepribadian siswa.

Dan pada kegiatan akhir, guru akan sedikit mengulas ataupun sekedar mengoreksi kesalahan yang dirasa sering terjadi selama materi tersebut berlangsung. Kemudian guru akan memberi tugas yang harus dikerjakan peserta didik dengan batas waktu yang ditentukan. Sebagai bentuk bantuan, guru akan memberikan beberapa link video penjelasan yang berkenaan dengan materi sehingga peserta didik tetap dapat mempelajari kembali materi tersebut dilain waktu.

Kegiatan penutup yang dilakukan guru diakhir pembelajaran dilakukan sangat baik, karena guru telah memberikan pemahaman, melakukan evaluasi serta memberikan bahan ajar untuk diluar jam pelajaran sehingga akan sangat membantu siswa dalam menyelesaikan tugas yang diberikan.

Menurut Abimanyu (dalam Anggraeni dan Akbar, 2018:64) kegiatan penutup dimaksudkan untuk memberikan gambaran menyeluruh tentang apa yang telah dipelajari oleh siswa, mengetahui tingkat pencapaian siswa baik sikap, pengetahuan, maupun keterampilan yang berkaitan dengan materi yang telah dipelajarinya. Adapun jenis kegiatan yang dapat dilakukan guru dalam menutup pembelajaran antara lain membuat rangkuman, memberikan tugas, memberikan tes, memberikan refleksi, membuat kesimpulan dan kegiatan lain yang sejenis.

\section{Evaluasi Penerapan Blended Learning pada Pembelajaran Bahasa Arab di SMPIT Ibadurrahman}

Adapun evaluasi yang dilakukan guru selama penerapan blended learning pada pembelajaran bahasa Arab ini dilakukan melalui beberapa evaluasi:

a. Self-Assesment atau yang biasa disebut dengan tes mandiri. Yaitu, penilaian kompetensi secara mandiri dengan cara mengerjakan tes yang terdapat pada buku paket yang dimiliki peserta didik.

Namun ini hanya berlaku untuk materi dengan tujuan kemahiran mendengar (mahârah istima') dan kemahiran menulis (mahârah kitâbah). Sedangkan untuk kemahiran berbicara (mahârah kalâm) dan kemahiran membaca (mahârah qirâ'ah) guru meminta peserta didik untuk merekam diri mereka untuk membaca teks berbahasa Arab 
maupun berbicara dalam bahasa Arab. Pemberian tugas ini dilakukan disetiap akhir pembahasan materi.

Pemberian tugas tidak selalu berbentuk soal dalam buku ataupun membuat video. Karena sesekali guru memanfaatkan berbagai website permainan seperti, Kahoot! dan Quizizz sebagai tes mandiri.

b. Tes oleh guru, yaitu penilaian pencapaian hasil belajar yang dilakukan guru setelah peserta didik menyelesaikan satu atau beberapa unit modul. Tes ini berupa Ujian Tengah Semester (UTS) atau Ujian Akhir Semester (UAS). Adapun Kriteria Ketuntasan Minimal (KKM) sebesar 75. Nilai ini memiliki kesamaan dengan pembelajaran yang biasa dilakukan di sekolah. Sehingga meskipun pembelajaran dilakukan dengan cara jarak jauh akan tetapi pemerolehan KKM tidak ada pengurangan.

Adapun bentuk soal UTS ataupun UAS yang diberikan adalah dalam bentuk soft file ( $p d f$ ) yang nantinya diberikan guru melalui grup Whatsapp sesuai dengan jadwal ujian yang diselenggarakan. Guru juga akan memberikan format pengisian ujian kepada pesera didik sehingga peserta didik diminta untuk mengisikan jawaban ujian di format yang telah diberikan. Jika waktu ujian telah habis maka peserta didik dapat mengirimkan format jawaban tersebut kepada guru melalui Whatsapp. Format pengisian jawaban sengaja dipersiapkan pihak sekolah karena akan memudahkan saat pemeriksaan hasil ujian. Pemeriksaan hasil ujian tidak dilakukan secara manual akan tetapi melalui aplikasi yang bernama Axcel. Cara kerjanya, aplikasi ini dapat men-scan format jawaban peserta didik kemudian hasil dari jawaban tersebut akan muncul secara otomatis.

Aplikasi ini telah secara khusus dipersiapkan oleh pihak kurikulum sekolah SMPIT Ibadurrahman untuk menghadapi ujian sekolah pada saat pendidikan jarak jauh. Dengan tujuan agar memudahkan guru untuk mengokreksi lembar jawaban para peserta didik.

Hasil evaluasi pembelajaran merupakan nilai akumulatif dari keseluruhan nilai baik dari membaca materi pembelajaran, nilai dari latihan soal diakhir pembelajaran, pemberian tugas, nilai UTS dan UAS.

Guru memberikan penilaian pembelajaran bahasa Arab yang sama pada saat pelaksanaan blended learning dan pada saat pembelajaran di sekolah langsung. Penilian pembelajaran bahasa Arab tetap terdiri dari 3 aspek yaitu kognitif, psikomotor dan afektif.

Penilaian secara kognitif dapat dilihat guru dari penilaian latihan soal, tugas dan hasil ujian baik UTS maupun UAS yang telah dilakukan peserta didik. Untuk penilaian 
psikomotor dapat dilihat dari cara peserta didik mengerjakan tugas, seperti tugas membuat video pada keterampilan membaca (mahârah qirâ'ah) dan keterampilan berbicara (mahârah kitâbah). Sedangan penilian afektif dapat dilihat melalui kehadiran peserta didik pada saat mengikuti virtual classroom. Penilaian afektif juga dapat dilihat dari keaktifan peserta didik dalam mengikuti proses pembelajaran serta pengerjaan tugas.

\section{Kendala Penerapan Blended Learning pada Pembelajaran Bahasa Arab di SMPIT Ibadurrahman}

Setelah beberapa kali menerapkan blended learning khususnya pada pembelajaran bahasa Arab terdapat beberapa kendala yang dialami oleh guru, diantaranya:

a. Kurangnya Sarana dan Prasarana.

Seperti tidak tersedianya LMS padahal penggunaan LMS sangat amat dapat membantu demi keberhasilan penerapan blended learning. Juga tidak adanya pelatihan guru sebelum penerapan blended learning ataupun pelatihan dalam melaksanakan pendidikan jarak jauh. Sehingga guru harus berusaha lebih keras demi menciptakan sistem pembelajaran yang menarik dan mudah dipahami. Blended learning juga pada awalnya dirasa cukup menyulitkan guru karena guru yang belum terbiasa melaksanakan pendidikan jarak jauh. Kekhawatiran guru tentang peserta didik yang akan merasa sulit memahami materi pembelajaran dan kurangnya minat peserta didik untuk mengikuti pendidikan jarak jauh.

b. Fasilitas yang Dimiliki Peserta Didik Berbeda

Fakta yang terjadi di lapangan tidak semua peserta didik memiliki handphone ataupun komputer pribadi. Ada beberapa murid yang handphone-nya masih meminjam kepada orang tua. Sehingga pada saat wali murid hendak berangkat kerja atau tidak sedang berada di rumah maka handphone tersebut akan dibawa dan dengan terpaksa peserta didik seringkali harus meminta izin kepada guru untuk tidak mengikuti pembelajaran.

Belum lagi perihal ketersediaan kuota internet dan jangkauan sinyal internet disetiap peserta didik dan guru berbeda, menjadi penyebab blended learning tidak dapat dilakukan dan dengan terpaksa harus berganti menjadi e-learning yang hanya memanfaatkan video pembelajaran yang dikirimkan guru. 
Hal ini sesuai dengan pendapat yang dikemukakan oleh Allen, dkk (dalam Syarif, 2012:239) bahwa sebuah pembelajarab dikatakan berbentuk blended atau hybrid Ketika porsi e-learning berada pada kisaran $20-79 \%$ digabungkan dengan tatap muka (face to face learning).

Tabel 1. Proportion of Content Delivered Online

\begin{tabular}{|l|l|l|}
\hline $\begin{array}{c}\text { \% on- } \\
\text { line }\end{array}$ & $\begin{array}{l}\text { Type of Course } \\
\text { (Module) }\end{array}$ & \multicolumn{1}{|c|}{ Typical Description } \\
\hline $0 \%$ & Traditional & $\begin{array}{l}\text { Course with no online technology used - content is } \\
\text { delivered in writing/orally }\end{array}$ \\
\hline $1-29 \%$ & Web Facilitated & $\begin{array}{l}\text { Course that uses web-based technology to facilitate } \\
\text { F2F course May use VLE or web pages to post } \\
\text { curriculum \& assignments }\end{array}$ \\
\hline $30-79 \%$ & Blended/Hybrid & $\begin{array}{l}\text { Course that blends online \& F2F delivery } \\
\text { Substantial proportion of content is delivered } \\
\text { online, typically uses online discussion \& typically } \\
\text { has a reduced number of F2F sessions. }\end{array}$ \\
\hline $80+\%$ & Online & $\begin{array}{l}\text { A course where most/all of the content is delivered } \\
\text { online. Typically no F2F meetings. }\end{array}$ \\
\hline
\end{tabular}

Allen, dkk (dalam Syarif, 2012:239)

c. Kurangnya Kerja sama Wali Murid

Keberhasilan blended learning ini dipengaruhi juga oleh kerja sama yang dilakukan wali murid. Sedangkan kenyataannya tidak jarang pada saat dilaksanakannya virtual classroom ada beberapa peserta didik yang meminta izin meninggalkan virtual classroom dikarenakan harus membantu orang tuanya. Ataupun ada beberapa orang tua yang dirasa kurang membantu memantau aktivitas peserta didik pada saat pembelajaran berlangsung ataupun memantau peserta didik dalam menyelesaikan tugas-tugasnya disekolah.

Beberapa kendala tersebut juga diungkapkan oleh Effendi dan Wahidy (2019:129) kekurangan blended learning diantaranya:

1) Media yang dibutuhkan sangat beragam, sehingga sulit diterapkan apabila sarana dan prasarana tidak mendukung.

2) Tidak meratanya fasilitas yang dimiliki pelajar, seperti komputer dan akses internet. Padahal dalam blended learning diperlukan akses internet yang memadai, apabila jaringan kurang memadai akan menyulitkan peserta dalam mengikuti pembelajaran mandiri via online.

3) Kurangnya pengetahuan masyarakat terhadap penggunaan teknologi. 


\section{SIMPULAN}

Berdasarkan hasil temuan dan pemabahasan yang telah dijelaskan penelitimaka dapat disimpulkan bahwa secara garis besar penerapan pembelajaran blended learning pada pembelajaran huruf hijaiyah yang dilakukan guru di kelas VII Akwat SMPIT Ibadurrahman sudah sangat amat baik dilakukan dan sesuai dengan teori-teori yang ada. Serta blended learning yang dilakukan mampu menjadi jalan keluar dari persoalan pelaksanaan pendidikan jarak jauh.

Adapun beberapa hasil temuan yang menjadi fokus bahasan peneliti adalah perencanaan, proses pelaksanaan yang terdiri dari kegiatan awal, kegiatan inti dan kegiatan akhir, evaluasi serta kendala yang dialami guru.

\section{DAFTAR PUSTAKA}

Anggraeni, P dan Akbar, A. (2018). Kesesuaian Rencana Pelaksanaan Pembelajaran dan Proses Pembelajaran. Jurnal Pesona Dasar, 6(2), 55-65.

Creswell, D.A. (2015). Penelitian Kualitatif dan Desain Riset. Yogyakarta: Pustaka Belajar.

Effendi, D. dan Wahidy, A. (2019). Pemanfaatan Teknologi dalam Proses Pembelajaran Menuju Pembelajaran Abad 21. Prosiding Seminar Nasional Pendidikan Program Pascasarjana Universitas PGRI Palembang, 125-129.

Karimna, K.I. (2019). Penerapan Metode Edutaiment Melalui Permainan Simak-Ulang-Ucap Untuk Meningkatkan Keterampilan Berbicara Bahasa Arab. Alsuniyat: Jurnal Penelitian, Sastra dan Budaya Arab, 2(1), 58-68.

Nikmawati, I.S. (2014). Korelasi Gaya Belajar Siswa Kelas VII dengan Hasil Belajar Mata Pelajaran Sejarah Kebudayaan Islam di Sekolah Menengah Pertama (SMP) Islam Durenan Trenggalek. Skripsi. Fakultas Tarbiyah dan Keguruan, Pendidikan Agama Islam, IAIN Tulungagung.

Syarif, I. (2012). Pengaruh Model Blended Learning Terhadap Motivasi dan Prestasi Belajar Siswa SMK. Jurnal Pendidikan Vokasi, 2(2), 234-249.

Thoha, M. (2012). Pembelajaran Bahasa Arab dengan Pendekatan Manajemen Berbasis Sekolah. OKARA, 1(7), 79-90.

Usman. (2018). Komunikasi Pendidikan Berbasis Blended Learning dalam Membentuk Kemandirian Belajar. Jurnalisa, 4(1), 136-150. 
Wardani, D.N., dkk. (2018). Daya Tarik Pembelajaran di Era 21 dengan Blended Learning. Jurnal Kajian Teknologi Pendidikan, 1(1), 13-18.

Wena, M. (2014). Strategi Pembelajaran Inovatif Kontemporer: Suatu Tinjauan Konseptual Operasional. Jakarta: Bumi Aksara.

Widiara, I.K. (2018). Blended Learning Sebagai Alternatif Pembelajaran di Era Digital. Purwadita, 2(2), 50-56. 